Rodwell, A. W. (1953). J. gen. Microbiol. 8, 238-247.

\title{
Factors affecting the Activation of the Ornithine Apode- carboxylase of a Strain of Lactobacillus
}

\author{
By A. W. RODWELL* \\ Medical Research Council Unit for Chemical Microbiology, \\ Biochemical Laboratory, Cambridge
}

\begin{abstract}
SUMMARY: The strain of Lactobacillus used (strain $30 a$ ) possessed decarboxylases specific for L-histidine, L-lysine and L-ornithine. The rate of decarboxylation increased after a lag period to a maximum value which was dependent on the concentration of pyridoxal. A number of factors was found to affect the rate of activation of the apoenzymes, or, it is thought, probably the rate of pyridoxal phosphate synthesis. Among these factors were: the presence in the test system of the specific substrate for the decarboxylase, the concentration of pyridoxal, and the $\mathrm{pH}$ value of the test system. Cells grown in medium deficient in both pyridoxin and folic acid had greatly decreased activation rates for ornithine apodecarboxylase, and pyridoxal phosphate synthesis was also decreased. 'The addition of folic acid to the system did not affect the rate of activation with folic acid-deficient cells. The addition of thymine to the test system increased the activation rate for folic acid-rich cells, but had no effect with folic acid-deficient cells; other purines were ineffective. It is concluded that some product of thymine metabolism which folic acid-deficient cells are unable to make is concerned with the biological phosphorylation of pyridoxal by this organism.
\end{abstract}

Bellamy \& Gunsalus (1944a) found that cells of Streptococcus faecalis grown in pyridoxin-deficient medium contained the apoenzyme of tyrosine decarboxylase. 'Pseudopyridoxine' activated the apoenzyme in living cells, but dried cells prepared from them required adenosine triphosphate (ATP) in addition (Bellamy \& Gunsalus, 1944b). With intact cell suspensions and pyridoxal at $1 \cdot 6 \times 10^{-5} \mathrm{M}$, complete activation was obtained almost immediately (Bellamy $\&$ Gunsalus, 1945). Experiments with the strain 30 a of Lactobacillus (Rodwell, $1953 a$ ) indicated that to obtain cells with high ornithine or lysine decarboxylase activity it was necessary to grow them in media containing concentrations of pyridoxin derivatives very greatly in excess of those required for maximum growth. The ornithine decarboxylase activity of cells grown in such complex media as casein liver-digest medium containing added pyridoxin $(10 \mu \mathrm{g} . / \mathrm{ml}$.) could be further increased in manometric experiments by testing in the presence of high concentrations of pyridoxal.

Ornithine apodecarboxylase was chosen for studies on pyridoxal activation rather than lysine apodecarboxylase because: $(a)$ it appeared to have a very low affinity for coenzyme and required a higher concentration for full activity; (b) it was more stable than lysine apodecarboxylase. With the basal medium they used, Bellamy \& Gunsalus (1945) found that apart from pyridoxin,

* Present address: Commonwealth Scientific and Industrial Research Organization, Animal Health Research Laboratory, Parkville, Melbourne, N.2, Australia. 
nicotinic acid, alanine, purines and pyrimidines, folic acid and related compounds all influenced the amount of complete tyrosine decarboxylase formed without affecting apoenzyme formation.

\section{MATERIALS AND METHODS}

Organism. The organism used, Lactobacillus sp. strain $30 a$, has been described previously (Rodwell, 1953a).

Growth media. For the experiments in which the effects of pyridoxal concentration, presence of substrate, and $\mathrm{pH}$ value, on the activation of apoenzyme in washed cell suspensions were studied, the medium used for growing the cells was casein liver digest medium. For the experiments in which the effects of a folic acid deficiency were studied, the semi-defined medium (Rodwell, $1953 a$ ) was used with the following modifications. The concentration of pyridoxin was decreased to $0 \cdot 1 \mu \mathrm{g}$. $/ \mathrm{ml}$., which allowed almost maximum mass of growth, although the cells were almost devoid of ornithine and lysine decarboxylase activity (Rodwell, 1953 $b$ ). For growth of folic acid-deficient cells, folic acid was either omitted altogether or added in concentrations ranging from 0.02 to $0.05 \mathrm{~m} \mu \mathrm{g}$. $/ \mathrm{ml}$. For folic acid-saturated cells the medium contained $1 \mu \mathrm{g}$. folic acid $/ \mathrm{ml}$. The yield of cells from the deficient medium varied from one-quarter to one-half of that obtained in the corresponding folic acid-rich medium. For the experiments in which the effect of the addition of thymine to the growth medium was studied, thymine was added at the rate of $20 \mu \mathrm{g} . / \mathrm{ml}$., together with $0 \cdot 1 \%(\mathrm{v} / \mathrm{v})$ Examen (Glaxo Laboratories Ltd.).

Expression of activities. When testing the ornithine decarboxylase activities of suspensions by activation of the apoenzyme with pyridoxal, the notation $Q_{\mathrm{Co}_{2}}$ (max.) was used to denote the rate/mg. dry wt. cells/hr., calculated from the linear portion of the progress curves. The rate of activation of the apoenzyme was calculated from graphs in which the rate of the reaction for each 5 min. interval was plotted against the reaction time, and is defined as the rate of increase in $Q_{\mathrm{CO}_{2}} / \mathrm{hr}$.

Preparation of ornithine and tyrosine apodecarboxylases. Ornithine apodecarboxylase was prepared from washed cells of strain $30 a$ grown in casein liver digest medium, by extraction of an acetone powder in the same way as for the preparation of histidine decarboxylase (Rodwell, 1953b). During this preparation the ornithine decarboxylase was almost completely dissociated. Tyrosine apodecarboxylase was prepared from cells of Streptococcus faecalis (Epps, 1944).

Assay of pyridoxal phosphate. Samples to be assayed were made alkaline with sodium hydroxide, boiled, cooled and neutralized (Green, Leloir \& Nocito, 1945). The pyridoxal phosphate content was assayed by means of tyrosine apodecarboxylase, using a standard curve prepared with calcium pyridoxal phosphate (Merck). Acetate buffer was used since Sloane-Stanley (1949) showed that phosphate interferes with the assay. 


\section{RESULTS}

Pyridoxal activation of ornithine apodecarboxylase in washed suspensions

Effect of pyridoxal concentration. The effect of concentrations of pyridoxal ranging in tenfold steps from $10^{-3}$ to $10^{-6} \mathrm{M}$ on the progress curves for ornithine decarboxylation is illustrated in Fig. 1. The rate of decarboxylation in the absence of pyridoxal was linear from the beginning of the reaction, whereas

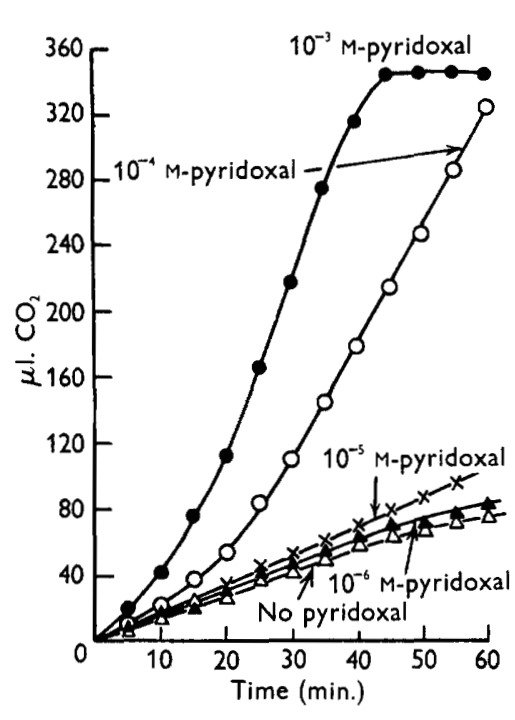

Fig. 1

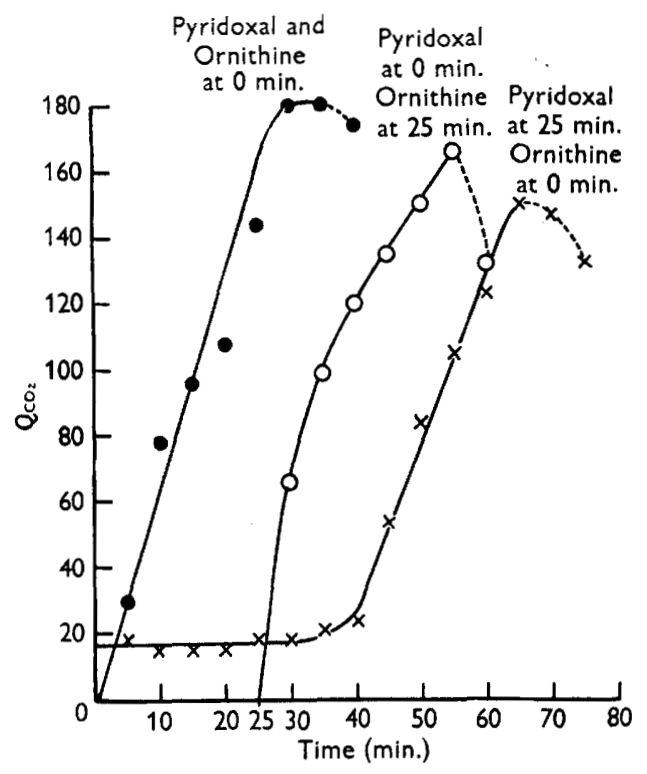

Fig. 2

Fig. 1. Effect of pyridoxal concentration on rate of ornithine decarboxylation by washed cell suspensions. Cells grown in casein liver-digest medium. Manometers contained: 0.2M-Mellvaine buffer, 1.4 ml.; washed cell suspension (8 mg. dry wt./ml.), $0.5 \mathrm{ml}$; pyridoxal hydrochloride solution or water, $0.1 \mathrm{ml}$; $0.033 \mathrm{M}$-ornithine (side-bulb), $0.5 \mathrm{ml}$.

Fig. 2. Effect of pyridoxal or substrate on the activation rate of ornithine apodecarboxylase in cell suspensions. Manometers contained: $0 \cdot 2 \mathrm{M}$-McIlvaine buffer $\mathrm{pH} \mathbf{5 \cdot 4 , 1} 1.0 \mathrm{ml}$; bacterial suspension ( $4 \mathrm{mg}$. dry wt./ml.), $0.5 \mathrm{ml}$.; $5 \times 10^{-3} \mathrm{M}$-pyridoxal (side bulb $\mathrm{I}$ ), $0.5 \mathrm{ml}$; $0.033 \mathrm{M}$-ornithine (side-bulb 2), $0.5 \mathrm{ml}$.

in the presence of pyridoxal the rate increased as the reaction proceeded, becoming constant in approximately $30 \mathrm{~min}$. after the addition of substrate in the presence of $10^{-4} \mathrm{M}$-pyridoxal, and in $20 \mathrm{~min}$ with $10^{-3} \mathrm{M}$-pyridoxal; $10^{-2} \mathrm{M}$-pyridoxal caused a slight inhibition of the final rate of decarboxylation. In subsequent experiments $10^{-3} \mathrm{M}$-pyridoxal was used. The rate finally achieved is referred to as $Q_{\mathrm{Co}_{2}}(\max$.$) , and the rate at which the reaction increases to$ this maximum value as the rate of activation.

Effect of the presence of substrate on the rate of activation. Ornithine was placed in one side-bulb of a series of double-bulb manometer vessels; pyridoxal solution to give a final concentration after tipping of $10^{-3} \mathrm{M}$ was placed in the 
second side-bulb; bacterial suspension and buffer were placed in the main compartments. After equilibrating, ornithine and pyridoxal were added together in one manometer, in the second pyridoxal was added first and ornithine $25 \mathrm{~min}$. later, in the third ornithine was added first and pyridoxal $\mathbf{2 5} \mathrm{min}$. later. The rate of activation in the three manometers is illustrated in Fig. 2. Pre-incubation of the cells with pyridoxal, or of cells with substrate, did not greatly alter the rate of activation. It appears that coenzyme is only formed when apoenzyme and substrate are both present; and that apoenzyme, substrate and coenzyme are in dynamic equilibrium. Later experiments in which pyridoxal phosphate assays were performed showed that when the reaction had stopped because of substrate exhaustion, pyridoxal phosphate concentration then decreased. With cell-free ornithine apodecarboxylase and pyridoxal phosphate, a constant rate was obtained immediately after adding substrate.

Effect of $\mathrm{pH}$ value on the activation rate and on the $Q_{\mathrm{Co}_{2}}(\max$.$) . The rates of$ activation and the $Q_{\mathrm{CO}_{2}}$ (max.) values were determined at a number of $\mathrm{pH}$ values ranging from 4 to 6.3 ; the results are shown in Fig. 3. Whereas the optimum $\mathrm{pH}$ value for the activity of the complete enzyme in intact cells was approximately $\mathbf{5 \cdot 5}$, the optimum for pyridoxal activation of the apoenzyme was higher than $\mathrm{pH} 6 \cdot 3$; the optimum for the cell-free ornithine decarboxylase was at $\mathrm{pH} \mathbf{5 \cdot 8 .}$

\section{Relative affinities of ornithine and tyrosine apodecarboxylases for pyridoxal phosphate}

The effect of pyridoxal phosphate concentration on the rate of the decarboxylation reaction for a cell-free preparation of ornithine decarboxylase is compared with that for a preparation of tyrosine apodecarboxylase in Fig. 4. The concentrations of pyridoxal phosphate required for half-maximum activity were approximately $1.2 \times 10^{-6}$ and $2 \cdot 0 \times 10^{-7} \mathrm{M}$ respectively.

\section{Effect of folic acid deficiency on decarboxylase formation}

Relative effects on histidine and ornithine decarboxylases. The effect of a deficiency of folic acid in the growth medium on the ornithine decarboxylase activity of the cells was compared with its effect on histidine decarboxylase activity, and, in one experiment, on the rate of glycolysis. The relative effects of growth in folic acid-deficient medium on histidine decarboxylase, and on ornithine decarboxylase after pyridoxal activation, are recorded in Table 1 , in which the activities in each experiment are expressed as percentages of the activities of the cells grown in the corresponding folic acid-rich medium. The results of these experiments indicated that a deficiency of folic acid in the growth medium had a relatively greater effect on the pyridoxal phosphaterequiring ornithine decarboxylase than on histidine decarboxylase, or upon the rate of glycolysis.

Effect of folic acid deficiency on the rate of activation. The rates of pyridoxal activation for folic acid-deficient and acid-rich cells were compared in several experiments. The rates of activation obtained in one experiment are illustrated 
Table 1. Relative effect of growth in folic acid-deficient medium on histidine decarboxylase activity, ornithine decarboxylase activity after pyridoxal activation, and on the rate of glycolysis of the cells.

The activities are expressed as \% of the activities of cells grown in the corresponding folic acid-rich medium.

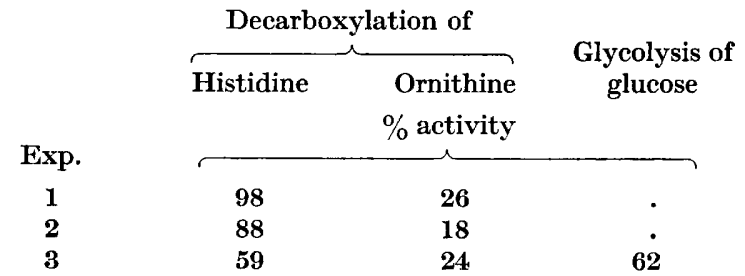

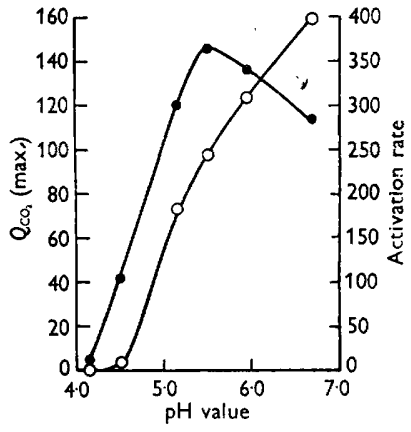

Fig. 3

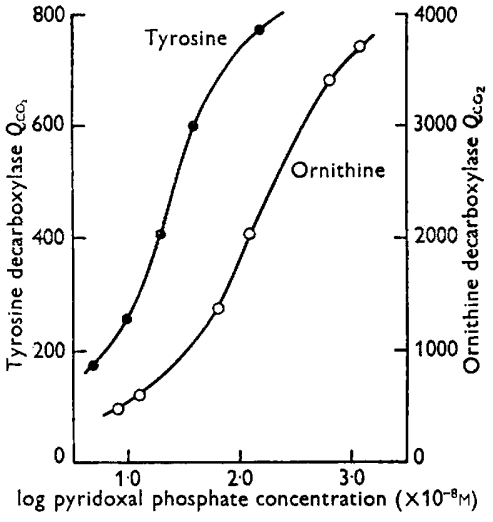

Fig. 4

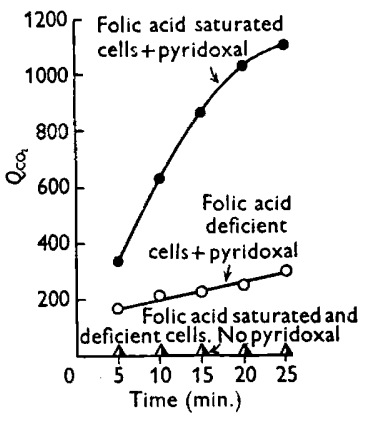

Fig. 5

Fig. 3. Effect of $\mathrm{pH}$ value on the rate of activation and on the activity of ornithine decarboxylase in cell suspensions. $\mathrm{O}-\mathrm{O}-\mathrm{O}=$ activation rate; $-0-0=$ maximum activity. Manometers contained : $0 \cdot 2 \mathrm{M}$-McIlvaine buffer, $1.4 \mathrm{ml}$; bacterial suspension (8 mg./ml. dry wt.), $0.5 \mathrm{ml}$; $2.5 \times 10^{-2} \mathrm{M}$-pyridoxal, $0.1 \mathrm{ml}$; $0.033 \mathrm{M}$-ornithine (sidebulb), $0.5 \mathrm{ml}$.

Fig. 4. Relationship between pyridoxal phosphate concentration and activation of tyrosine and ornithine apodecarboxylases. Manometers contained: (for ornithine) $\mathbf{0 \cdot 2} \mathrm{M}$-acetate buffer pH 5.6, 1.4 ml.; enzyme solution, $0.1 \mathrm{ml}$; pyridoxal phosphate, $1.0 \mathrm{ml}$.; $0.1 \mathrm{M}$ ornithine (side-bulb), $0.5 \mathrm{ml}$; $\mathrm{N}_{2}$ as gas phase; (for tyrosine) $0.2 \mathrm{M}$-acetate buffer $\mathrm{pH} 5.5$, $1.0 \mathrm{ml}$; enzyme solution, $0.25 \mathrm{ml}$.; pyridoxal phosphate solution, $0.5 \mathrm{ml}$.; $0.033 \mathrm{M}-$ tyrosine suspension (side-bulb), $0.5 \mathrm{ml}$.; $\mathrm{N}_{2}$ as gas phase.

Fig. 5. Effect of folic acid in the growth medium on the rate at which cells form the complete ornithine decarboxylase in the presence of pyridoxal. Cells grown in semi-defined medium (pyridoxin concentration $0.1 \mu \mathrm{g} . / \mathrm{ml}$; folic acid $1 \mu \mathrm{g} . / \mathrm{ml}$. for saturated cells, none added for deficient cells). Washed suspensions of cells tested: $(a)$ in the absence of pyridoxal; $(b)$ in the presence of $10^{-3} \mathrm{M}$-pyridoxal.

in Fig. 5. The activation rate for the folic acid-rich cells was 3800 , and for the deficient cells was 400 .

Effect of folic acid deficiency on pyridoxal phosphate synthesis. The suspensions were those used to illustrate the effect of folic acid deficiency on the activation rate (Fig. 5). After decarboxylation reaction had proceeded for 25 min., the 
manometers were dismantled, sodium hydroxide added to each cup and the contents then boiled and assayed for pyridoxal phosphate. Control mixtures were treated in the same way to obtain the initial pyridoxal phosphate content of the cells. The results of the assays, expressed as $\mu \mathrm{g}$. pyridoxal phosphate/mg. dry wt. of cells, are given in Table 2 . The results are in accord with the marked differences in the activation rates of these two suspensions (Fig. 5). In an earlier experiment in which the decarboxylation reaction was allowed to proceed to the point of complete substrate exhaustion, no synthesis of pyridoxal phosphate was found, in agreement with the idea expressed previously that when the reaction has proceeded to completion, the coenzyme may break down again.

\section{Table 2. Effect of folic acid deficiency on pyridoxal phosphate synthesis in cell suspensions}

Decarboxylation reaction followed manometrically (Fig. 5). Manometers contained : acetate (pH 5.5), $1.5 \mathrm{ml}$; bacterial suspension (=2.5 mg. folic acid-deficient cells, $2.8 \mathrm{mg}$. saturated cells), $0.25 \mathrm{ml}$; 0.1 M-ornithine, $0.5 \mathrm{ml}$.; $0.01 \mathrm{M}$-pyridoxal solution, $0.25 \mathrm{ml}$. After 25 min. reaction manometers dismantled, $0.25 \mathrm{ml} . \mathrm{N}-\mathrm{NaOH}$ added and contents assayed for pyridoxal phosphate.

$\begin{array}{lcc} & \begin{array}{c}\text { Deficient cells } \\ \mu \mathrm{g} . \text { pyridoxal }\end{array} \\ & \begin{array}{c}\text { Saturated cells } \\ \text { phosphate/mg. dry wt. cells }\end{array} \\ \text { Initial } & 0 \cdot 06 & 0 \cdot 06 \\ \text { After 25 min. } & 0 \cdot 08 & 0 \cdot 34 \\ \text { Synthesis } & 0 \cdot 02 & 0 \cdot 28\end{array}$

\section{'Inhibition of pyridoxal activation by 7-methylpteroylglutamic acid}

In several experiments in which it was tried, the rate of activation with folic acid-deficient cells was not increased by the addition of folic acid to the test system; it was necessary that the cells be grown in the presence of folic acid. Inhibition of ornithine decarboxylation by comparatively high concentrations of the analogue 7-methylpteroylglutamic acid was observed. The sensitivity varied with different suspensions, and could be correlated with an inhibition of the pyridoxal activation process rather than with an inhibition of the decarboxylase. The approximate concentrations required for a $20 \%$ inhibition of the maximum rate for several suspensions are recorded in Table 3 . The same suspension was used for experiments $(b)$ and $(c)$ in Table 3, but it was found that after storage the ability of the suspension to form the complete enzyme from pyridoxal had been largely lost, although there was no deterioration in the activity of the suspension when tested in the absence of pyridoxal. An inhibition of the rate of activation was also observed in these experiments in the presence of the inhibitor.

\section{Effect of thymine on pyridoxal activation}

Bellamy \& Gunsalus (1945) reported that in addition to folic acid, purines and pyrimidines when added to the basal medium increased the tyrosine decarboxylase activity of Strep. faecalis without affecting apoenzyme formation. The semi-defined medium used for cultivating strain $30 a$ contains the purine 
adenine, and the pyrimidine uracil. The addition of thymine, but not of guanine, xanthine or hypoxanthine, to medium deficient in folic acid, increased both the rate of pyridoxal activation of the cells, and the $Q_{\mathrm{CO}_{2}}$ (max.) value.

\section{Table 3. Inhibition of ornithine decarboxylase activity of bacterial suspensions by 7-methylpteroylglutamic acid}

Suspension and growth medium

(a) Cells grown in semi-defined medium (pyridoxin $0 \cdot 1 \mu \mathrm{g} . / \mathrm{ml}$.). Suspension inactive in the absence of pyridoxal

(b) Cells grown in casein liver digest medium. Relatively high activity without pyridoxal, activity increased by pyridoxal

(c) Same suspension as for $(b)$, but after $24 \mathrm{hr}$. storage at $4^{\circ}$. Ability to form complete enzyme from pyridoxal lost

(d) Cells grown in casein liver-extract medium. Ornithine decarboxylase saturated with coenzyme. No increase in activity with pyridoxal

(e) Cell-free enzyme

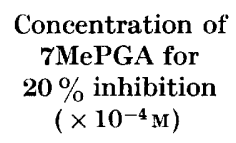

Concentration of 7MePGA for $20 \%$ inhibition

$\left(\times 10^{-4} \mathrm{M}\right)$

$\mathbf{3} \cdot \mathbf{8}$

$9 \cdot 5$

$19 \cdot 0$

$47 \cdot 0$

$30 \cdot 0$

$(a),(b)$ and $(c)$ tested in the presence of $10^{-3} \mathrm{M}$-pyridoxal and inhibitions calculated from $Q_{\mathrm{CO}_{2}}$ (max.) values; $(d)$ tested without activator; $(e)$ tested with excess pyridoxal phosphate.

Table 4. Effect of thymine on pyridoxal activation of apoenzyme in folic acid deficient and saturated cells

Manometers contained: acetate buffer (pH 5.5), $1.5 \mathrm{ml}$; bacterial suspension $(=1.5 \mathrm{mg}$. dry wt.), $0.25 \mathrm{ml}$; thymine $(1 \mathrm{mg} . / \mathrm{ml}$.) or water, $0.15 \mathrm{ml}$.; $0.1 \mathrm{M}$-ornithine, $0.5 \mathrm{ml}$.; $0.02 \mathrm{M}$ pyridoxal, $0 \cdot 1 \mathrm{ml}$.

Growth medium
(semi-defined $+0 \cdot 1 \%(\mathrm{v} / \mathrm{v})$
Examen) additions
$1 \mu \mathrm{g} . / \mathrm{ml}$. folic acid
$1 \mathrm{~m} \mu \mathrm{g} . / \mathrm{ml}$. folic acid
No folic acid added

\begin{tabular}{|c|c|}
\hline \multicolumn{2}{|c|}{$Q_{\mathrm{CO}_{2}}(\max )}$. \\
\hline -thymine & t thymine \\
\hline 780 & 1100 \\
\hline 540 & 490 \\
\hline 280 & 270 \\
\hline
\end{tabular}

The effect of thymine on pyridoxal activation of the apoenzyme in folic acid-deficient and saturated cells was then studied. The effect of thymine on the maximum rates is recorded in Table 4. Thymine caused an increase in the $Q_{\mathrm{CO}_{2}}$ (max.) with cells grown in the presence of a high concentration of folic acid, whereas folic acid-deficient cells did not respond to thymine. The rate of activation with folic acid-rich cells was also increased by thymine from 1700 to 4300.

Finally, the combined effects of folic acid deficiency and growth in the presence and absence of thymine were studied. The suspensions were in each case tested in the presence and absence of thymine. The $Q_{\mathrm{CO}_{2}}$ (max.) values obtained are recorded in Table 5. In this experiment also the maximum activity of cells grown in medium deficient in folic acid, and lacking thymine, was not increased by testing them in the presence of thymine. 
Table 5. Effect of thymine on pyridoxal activation in cells grown in medium deficient and rich in folic acid, and with and without the addition of thymine

Nanometers contained: acetate buffer $(\mathrm{pH} \mathrm{5.5),1.4} \mathrm{ml}$; bacterial suspension (=1.2 to $1.4 \mathrm{mg} . / \mathrm{ml}$. dry wt.), $0.25 \mathrm{ml}$; thymine (1 mg./ml.), $0.1 \mathrm{ml}$.; $0.01 \mathrm{M}$-pyridoxal, $0.25 \mathrm{ml}$; 0.1 M-ornithine, $0.5 \mathrm{ml}$.

Additions $/ \mathrm{ml}$. medium (semi-defined medium $+0 \cdot 1 \%(v / v)$

$\begin{array}{lcccc}\overbrace{\text { Folic acid }}^{\text {Examen })} & \text { Thymine } & \overbrace{- \text { Thymine }}^{\text {Q Thymine }} \\ 1 \mu \mathrm{g} . & - & 1000 & 1240 \\ 1 \mu \mathrm{g} . & 20 \mu \mathrm{g} . & 1140 & 1280 \\ 0.1 \mathrm{~m} \mu \mathrm{g} . & - & 660 & 640 \\ 0.1 \mathrm{~m} \mu \mathrm{g} . & 20 \mu \mathrm{g} . & 900 & 1100\end{array}$

\section{DISCUSSION}

The concentration of pyridoxal required to obtain maximum ornithine decarboxylase activity with washed suspensions of cells of the strain $30 a$ lactobacillus, is greater than that required for full activation of tyrosine apodecarboxylase with cells of Streptococcus faecalis; nor is there a delay with cells of the latter organism before full activity is reached (Bellamy \& Gunsalus, 1945). Possible explanations for these differences are: $(a)$ pyridoxal may only enter cells of strain $30 a$ at a comparatively slow rate; $(b)$ strain $30 a$ may have a relatively inefficient pyridoxal phosphorylating system; $(c)$ ornithine apodecarboxylase may have a relatively low affinity for the coenzyme, and a high concentration must be maintained by the cell to saturate the apoenzyme. The concentrations of pyridoxal phosphate required to obtain half maximum activity for tyrosine and ornithine apodecarboxylases were found to be $2 \cdot 0 \times 10^{-7}$ and $1.2 \times 10^{-6} \mathrm{M}$ respectively.

It has been suggested that apoenzyme, substrate and pyridoxal must all be present before coenzyme synthesis occurs. If this be true, the effects of folic acid deficiency on the activation rates, pyridoxal phosphate synthesis, and on the $Q_{\mathrm{CO}_{2}}$ (max.) values, could all be explained by a decreased formation of apoenzyme in cells grown in folic acid-deficient medium. The effect of folic acid deficiency on apoenzyme formation was not investigated. There seems little reason to suppose, however, that the formation of the apoenzyme of ornithine decarboxylase would be affected by folic acid deficiency to a greater degree than histidine decarboxylase, or than the constitutive enzymes concerned with glycolysis. The experiments with 7-methylpteroylglutamic acid also support the view that cells grown in medium deficient in folic acid have a decreased ability to form coenzyme from pyridoxal. Martin \& Beiler (1947) found that the 3:4-dihydroxyphenylalanine (dopa) decarboxylase of rat kidney was inhibited by 7-methylpteroylglutamic acid, and that the inhibition was annulled by folic acid; tyrosine decarboxylase of Strep. faecalis was much less sensitive under the same conditions. They inferred from this evidence that folic acid forms part of the dopa decarboxylase system. It would appear 
likely that in the experiments of Martin \& Beiler folic acid was concerned with the maintenance of pyridoxal phosphate concentration; Green et al. (1945) had previously shown that dopa decarboxylase requires pyridoxal phosphate.

Bellamy \& Gunsalus (1945) reported that the presence of purines and pyrimidines, as well as folic acid, in the growth medium, all influenced the formation of the holoenzyme of tyrosine decarboxylase in cells of Strep. faecalis without affecting apoenzyme formation. In the present studies, the inclusion of thymine in the growth medium increased the $Q_{\mathrm{CO}_{2}}$ (max.) values of the cells grown in it, and thymine also had an effect on the pyridoxal activation system in washed suspensions. It increased both the rate and the $Q_{\mathrm{CO}_{2}}$ (max.) value of suspensions of cells grown in folic acid-rich media, but was without effect with cells grown in media poor in folic acid and lacking this pyrimidine. It seems probable, therefore, that some product of thymine metabolism, which washed suspensions of folic acid-deficient cells are unable to make, is concerned with the uptake or phosphorylation of pyridoxal by this organism. There is evidence that both the active form of folic acid and vitamin $B_{12}$ are involved in the conversion of thymine to thymidine and to other deoxyribosides (Shive, Eakin, Harding, Ravel \& Sutherland, 1948; Franklin, Stokstad, Hoffman, Belt \& Jukes, 1949; Jukes, Broquist \& Stokstad, 1950).

I wish to thank Dr E. F. Gale for his encouragement and advice. I am indebted to the Medical Research Council of Great Britain for a generous grant during the period of this work, which was carried out during special study leave from the Division of Animal Health and Production of the Commonwealth Scientific and Industrial Research Organization, Australia.

\section{REFERENCES}

Bellamy, W. D. \& Gunsalus, I. C. (1944a). Tyrosine decarboxylation by streptococci: growth requirements for active cell production. J. Bact. 48, 191.

Bellamy, W. D. \& Gunsalus, I. C. $(\mathbf{1 9 4 4 b})$. The function of pyridoxine and pyridoxine derivatives in the decarboxylation of tyrosine. J. biol. Chem. 155, 557.

Bellamy, W. D. \& Gunsalus, I. C. (1945). Tyrosine decarboxylase. II. Pyridoxin deficient medium for apoenzyme production. J. Bact. 50, 95.

EPPS, H. M. R. (1944). Studies on bacterial amino-acid decarboxylases. 2. 1(-)Tyrosine decarboxylase from Streptococcus faecalis. Biochem. J. 38, 242.

Franklin, A. L., Stokstad, E. L. R., Hoffman, C. E., Belt, M. \& Jukes, T. H. (1949). Inhibition of growth of Escherichia coli by 4-aminopteroylglutamic acid and its reversal. J. Amer. chem. Soc. 71, 3549.

Green, D. E., Leloir, L. F. \& Nocitro, V. (1945). Transaminases. J. biol. Chem. $161,559$.

Jukes, T. H., Broquist, H. P. \& Stokstad, E. L. R. (1950). Vitamin $B_{12}$ and 'Citrovorum Factor' in the nutrition of Lactobacillus leishmannii and Leuconostoc citrovorum. Arch. Biochem. 26, 157.

Martin, G. J. \& Beiler, J. M. (1947). Inhibition of the action of dopa decarboxylase. Arch. Biochem. 15, 201.

Rodwell, A. W. (1953 $a$ ). The occurrence and distribution of amino-acid decarboxylases within the genus Lactobacillus. J. gen. Microbiol. 8, 224. 
Rodwell, A. W. (1953b). The histidine decarboxylase of a species of Lactobacillus; apparent dispensability of pyridoxal phosphate as coenzyme. J.gen. Microbiol. 8, 233.

Shive, W., Eakin, R. E., Harding, W. M., Ravel, J. \& Sutherland, J. C. (1948). A crystalline factor functionally related to folic acid. J. Amer. chem. Soc. 70, 2299.

Sloane-Stanley, G. H. (1949). The use of tyrosine apodecarboxylase of Streptococcus faecalis $R$ for the estimation of codecarboxylase. Biochem. J. 44, 567.

(Received 14 August 1952) 